Historic, Archive Document

Do not assume content reflects current scientific knowledge, policies, or practices. 



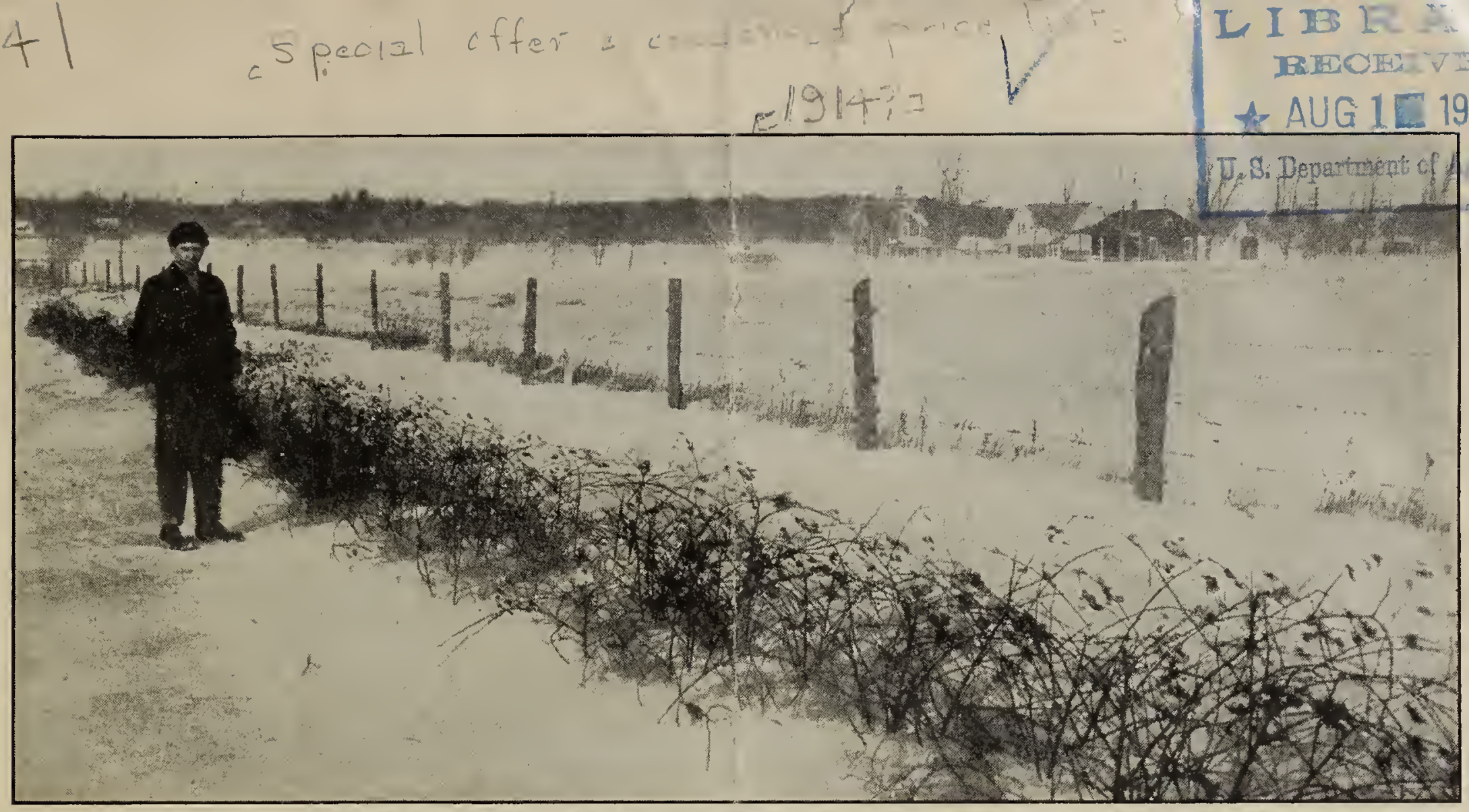

A row of Macatawa Blackberry plants, photographed February 8, I913. Hardy as an oak tree

\section{MONEY IN GROWING BERRIES}

\section{This is a personal message to all my friends and customers. So many of you have written asking questions, and desiring further information regarding berries, that $\mathbf{I}$ am answering you all in this way.}

The main thing that most of you want to know is: "How much can I make out of growing berries?" I say without any hesitation that $\$ 500$.00 an acre every year is as little as any one should expect if he really attends to business, takes care of the plants, and puts as much attention into growing berries as he would into any other line of business. Berry-growing is a business, and in order to make the big money you must run it on business principles. The way to succeed is to plant the new and most productive berries, that produce finer fruit and more of it-fruit that brings the highest prices in the markets. I've been growing berries all my life, and I am not a young man any more, either. If I can make $\$ 500.00$ an acre growing berries, there is no reason why you can't; because there are no secrets about berry-growing, and my catalogue tells you plainly just how to go at it to make the most money.

The thing to do now is to make a start. You may hesitate to begin planting because you think there are secrets to the trade, but there aren't; and I want you, right now, to decide that you are going to plant berries this spring, and test for yourself the truth of my statements that there is more money in berry-growing than in any other branch of agriculture or horticulture requiring the same amount of effort. To make it easy for you to start, I have prepared three model collections, and I list them here-one for the back-yard garden, another for an acre, and another for five acres. Any one will bring in to you the next year several limes what it cost, and your profits will jump rapidly every year after that.

I just gol a letter today from a good friend and customerPercy Brock, of Waterford, Ontario. Mr. Brock writes that a neighbor of his, George Sewel, cleated $\$ 2,500.00$ on berries last season. Another customer writes me of a man who made $\$ 800.00$ an acre from Raspberries and Blackberries, and a third customer tells me that he himself has cleared \$I,000.00 from an acre of Strawberries in three years. Now these men, and others who have been making big profits out of berrygrowing, are some of them farmers who never tried berrygrowing until a few years ago, and others are city men who took up berry-growing as a side line. If these men can grow berries so successfully, you certainly can.
The reason the berry business is so profitable now is that the demand for the fruit has increased out of all proportion to the increase in the area planted to them. One cause for this is that every day thousands leave the country for the city, and there is no one to take their places on the farm growing berries. Berry-growing has been neglected and overlooked, and, with the population of the cities increasing ten per cent or more each year, it will take many years before the supply catches up with the demand, if it ever does. People used to say' that apple-growing would be overdone, and that there would be no money in orchards; yet the fact remains that orchards in bearing now produce more money, acre for acre, than they did ten years ago. The same is true of berries. Even when the greatest supply reaches the city markets, the prices stay up pretty well, and the wholesalers have no trouble in disposing of their entire stock to the grocers. Just think how much you have to pay for berries now, and contrast it with what you paid only a few years ago. Berries are not going to go lower-the increase in the use of luxuries among the people of the cities will more than take care of any increased production.

Read my catalogue again; it is full of money-making ideas. Look over page 3 a second time, and see what you can do on five acres. If you aren't fixed so that you can plant five acres, study the story of the Himalaya Berry on page Io, read what people say about it on page I4, and then look over those new varieties of Blackberries listed on pages 15 and 16 . Then don't forget to turn to page 23 and read the descriptions of the Strawberries that I offer in greatly improved varieties which are bound to give you paying crops.

After you have read the catalogue, make out the list of those berries you need and send it to me. If you are in doubt about just what you want to fix up your place for berrygrowing, or about the varieties you want to grow in your home dooryard, just ask me about it, and I'll tell you everything I can. It's a pleasure to correspond with people who are interested in berry-growing, so write me a letter, anyway. When you order, I will give my personal attention to seeing that your order is filled, when you want it, with first-class stock, and will see that it reaches you in first-class condition.

\section{A. Mitting, Berrydale Experiment Gardens, Holland, Michigan}




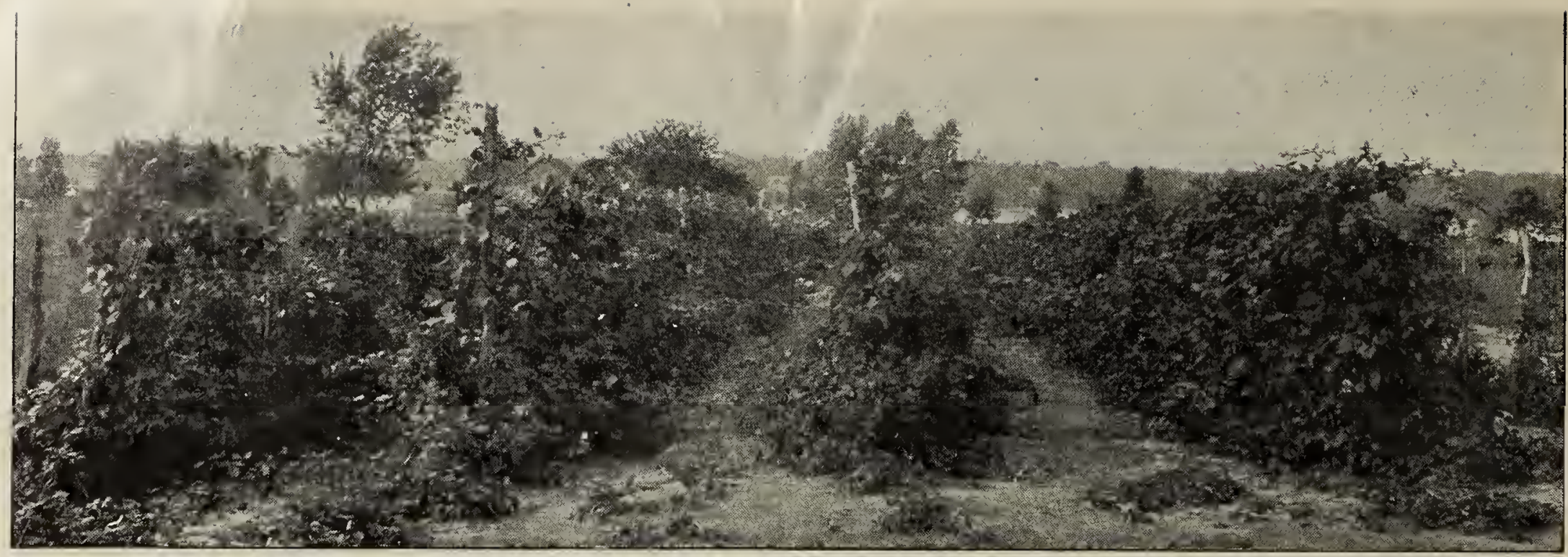

Himalaya plants two, three, and four years old, three miles from Holland, bearing very heavy crops in IgI2

\section{These 40 Berry Plants and Roses for $\$ 2.50$}

Here's an offer that I think you can't resist, because all the plants in it are first-class, productive varieties, and furnish just the food you want on your table-Blackberries, Himalaya Berries, Currants, Red Raspberries, Black Raspberries, Gooseberries and Grapes. Just think how much you would save in a year if you raised all these fruits yourself, instead of sending to the grocery store for them. Because flowers ought to be part of every garden, I have included four of the finest Rose-bushes in this collection. The whole list is worth $\$ 4.38$ at my regular prices, and most nurseries would charge you a great deal more for the plants. Just to show you the quality of the stock, and get you interested in the Berrydale Experiment Gardens, I will send you the entire collection by express for only $\$ 2.50$. Here is the list:

I Macatawa Blackberry.

2 Giant Himalaya Berries. I 2 months old.

2 Perfection Currants. 2 years old.

2 Boskoop Giant Black Currants, 2 years old.

6 Shepard's Pride Red Raspberries.
6 Plum Farmer Black Raspberries.

2 Mitting's Whinham Gooseberries, 2 years old.

2 Golden Drop Gooseberries, 2 years old.

6 Ancient Briton Blackberries.
3 Catawba Grapes.

I Dcrothy Perkins Rose, pink.

I Dorothy Perkins Rose, white.

I Lady Gay Rose.

I Blue Rambler Rose.

\section{A Bigger Collection at Less than Half-price}

There are a lot of people so situated that they can rent or buy an acre of land for berries, or perhaps already have an acre that they could use for a berry-plantation. Here is a collection that easily should bear $\$ 500.00$ worth of fruit next year. The varieties are all the best that can be had. From a patch like this you could supply all your family needs, put up in cans all the berries you possibly could use, have bushels of fruit to sell to your neighbors and the nearby grocers, and still have lots of it to ship away. The collection is arranged so that the fruit matures at different times, making it easy for one person to do all the work on the patch. Think how nice it would be, when Blackberries are selling for 15 to 25 cents a quart, to have ten to fifteen crates to send to market, and how much money you could make with 200 of these improved new Red Raspberries I haven't got room here to give descriptions of all these plants, but you will find full details about them in my 1913 Berry Book -if you have mislaid your copy, send me a postal, and I will mail you another. Here is the list of plants in this special oneacre collection:

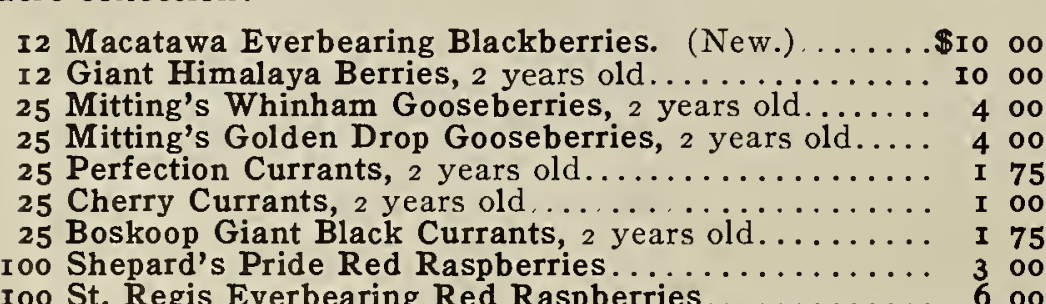

Ioo Plum Farmer Black Raspberries............. \$I 25 Ioo Cumberland Black Raspberries. ............. I 25 roo Lucretia Dewberries..................... I 00 roo Eldorado Blackberries................. I 50 I2 Crimson Winter Rhubarb................. I 00 I 2 Victoria Rhubarb.................... I 00 I 2 Catawba Grapes........................ I 00

50 Roses for hedges, 4 colors, I-year-old plants...... 500

You will notice that this list totals up $\$ 54.50$. I will fill this order just as it stands for $\$ 26.50$, cash with the order, and I can assure you that if you plant it this spring you will tell me next year that it is the best investment you ever made.

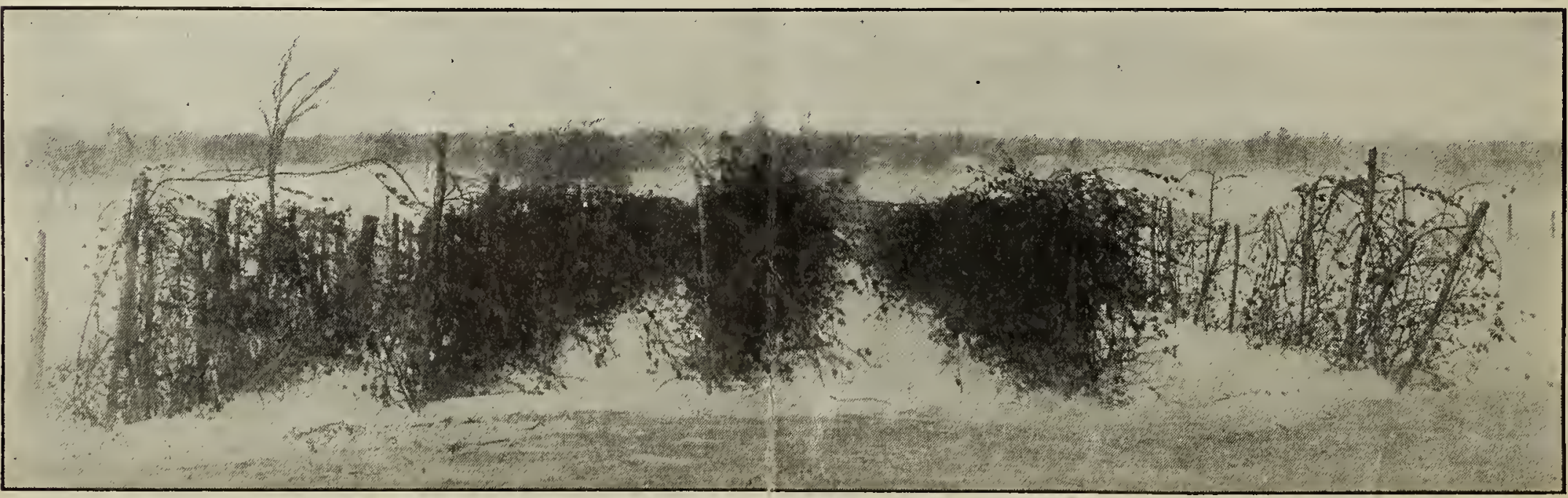

Himalaya plants in winter. Same field shown in upper picture. Photograph taken February 8, I9I3. We do not protect the plants 


\section{A Five-Acre Berry Farm Costing $\$ 277.13$ Should Pay You $\$ 2,000.00$ Every Year}

How would you like to own a five-acre berrypatch that puts $\$ 2,000.00$ in the bank every year? Looks good, doesn't it? On this basis your berrypatch should be worth at least $\$ 7,000.00$ an acre, or $\$ 35,000.00$ for the place.

Down in Norfolk County, Massachusetts, there is a fruit-farm of only five acres, which has netted over $\$ 2,000.00$ a year. The owner purchased the rough land about six years ago and planted berries and currants. For the first two years he lived in Boston and ran the fruit farm "on the side."

You can have such a place-if you make the start this spring you can begin to bank some of the profits next year. I know you cannot invest your money in any business that will give higher, safer, or steadier income than berry-growing.

You will want a good assortment of fruit, and I advise Himalaya Berry, Plum Farmer Black Raspberry, Shepard's Pride Red Raspberry, Cherry Currants, and others.

My Berry Book tells about the wonderful Himalaya Berry, the greatest small fruit ever grown in this country. The second season after planting, an acre of these berries should yield I,500 to 2,000 pounds of fruit; the next year it should yield ten tons or more. Our average yield is 16,000 quarts to the acre- and we sell the berries for 12 cents a quart.

Plum Farmer is the best Black Raspberry I have ever grown. The fruit is immense often an inch in diameter; the color is dark, grayish brown; fruit ripens early and most of the crop can be picked during a period of four to six days.

Shepard's Pride Red Raspberry is far ahead of any kind I know. The berries are velvety crimson, an inch or so long, solid, and with a sweet and delicious flavor. They ripen here about June 20 , which is several days earlier than any other variety.

\section{What It Takes to Make a Five-Acre Berry Farm}

On this page I show a good ground-plan for a five-acre berry farm. You can see the entire arrangement, and I believe the illustration will show you exactly what I have in mind. Notice the house and the barn.

There are hedges of Himalaya Berry at the sides, with roses and shrubbery in front. Over in the corner is a pasture, and all the rest of the farm is given up to berryfields and gardens, except a quarter-acre, which is reserved for chickenhouses and yards. Now the cost of such a fiveacre farm as this is very little. The price of land
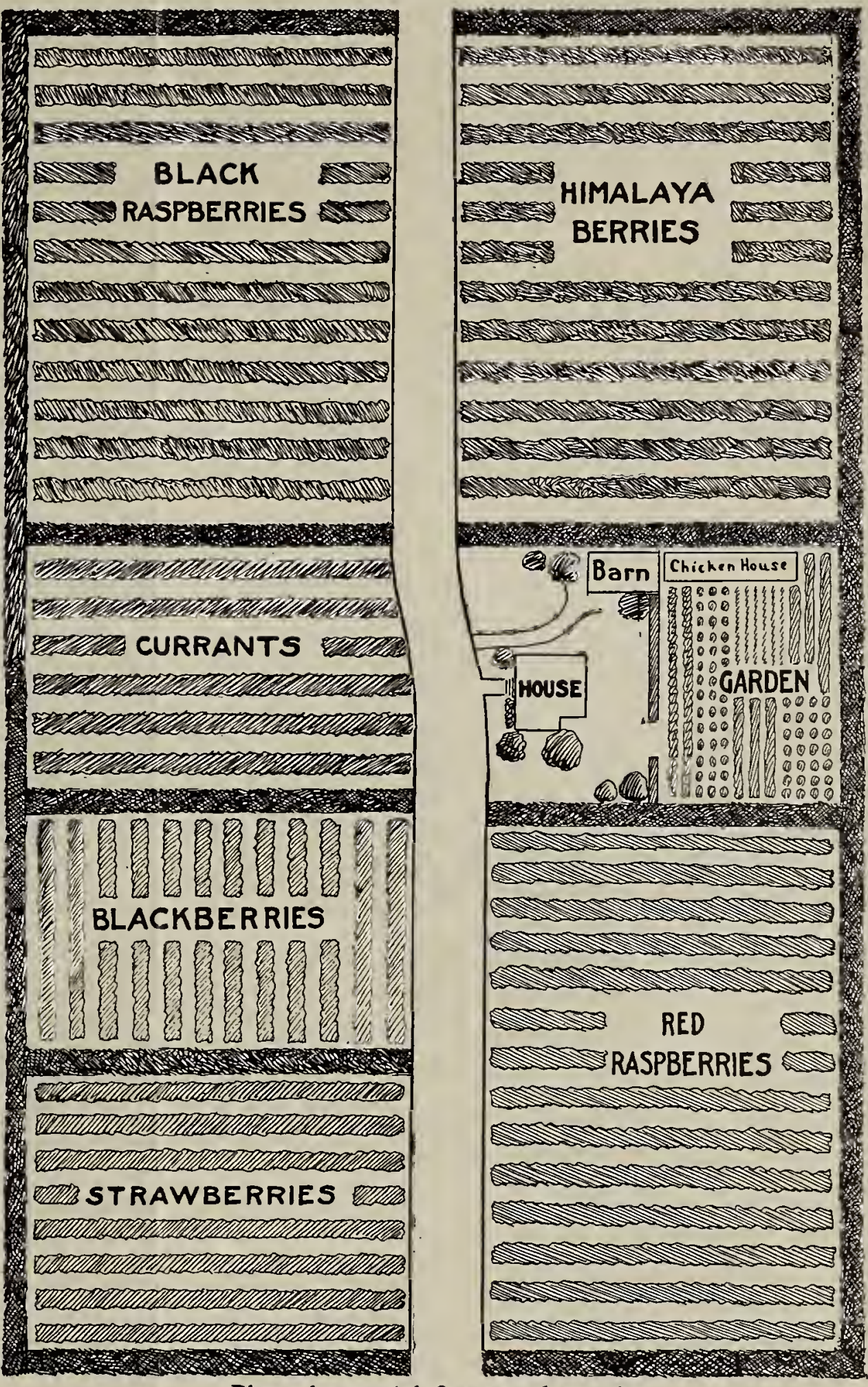

Plan of a model five-acre berry farm

and house varies in the different localities, so we won't attempt to make an estimate. You could rent a place, if you wished, because berries come into bearing in one year.

I've put a lot of thought into a planting that would give just the most money possible out of berries and still not make the owner work too steadily-I don't like to work all the time, and I don't think you do, either; it's a lot easier to have things fixed so that we can rest sometimes and work sometimes. The list of plants required for this five-acre farm is given here:

I Acre Himalaya Berries, I 2 months old, 5 xro ft. apart,

900 plants............................ $\$ 45$ I Acre Plum Farmer Black Raspberries, $5 \times 5$ ft. apart,

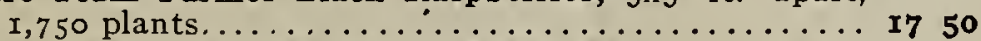
I Acre Shepard's Pride, Red Raspberries, $2 \times 6$ ft. apart,

3,000 plants....................... 75 oo

1/. Acre Ancient Briton Blackberries, 875 plants...

$\$ 4663$ plants...

$1 / 2$ Acre Strawberries, half King Edward, half Dunla ft. apart, 5,000 plants, special offer........

roo Macatawa Blackberries (new) to work up s $\$ 2,000.00$ to $\$ 2,500.00$. The plants that I list are all intended for the Eastern and Northern States. In the Southern States I would advise the use of a slightly different assortment, including these varieties, in altitudes of from I,00o feet to the sea-level:

Macatawa Berry, Himalaya Berry, Logan Berry, Mammoth Blackberry, Burbank's Pheromenal Berry, Oregon Evergreen Blackberry, Dewberries, Strawberries.

At places with an altitude of from I,000 to 2,500 feet, Gooseberries, Currants, Rhubarb, Black and Red Raspberries and Blackberries, such as Eldorado and Lawton, thrive well. The berry business is very profitable in the South, because southern growers can ship earlier than northern growers, and will get top-notch prices.

One great reason for planting a good lot of berries is that when you have a big supply the buyers will come to you, and bid against each other for your entire crop. 


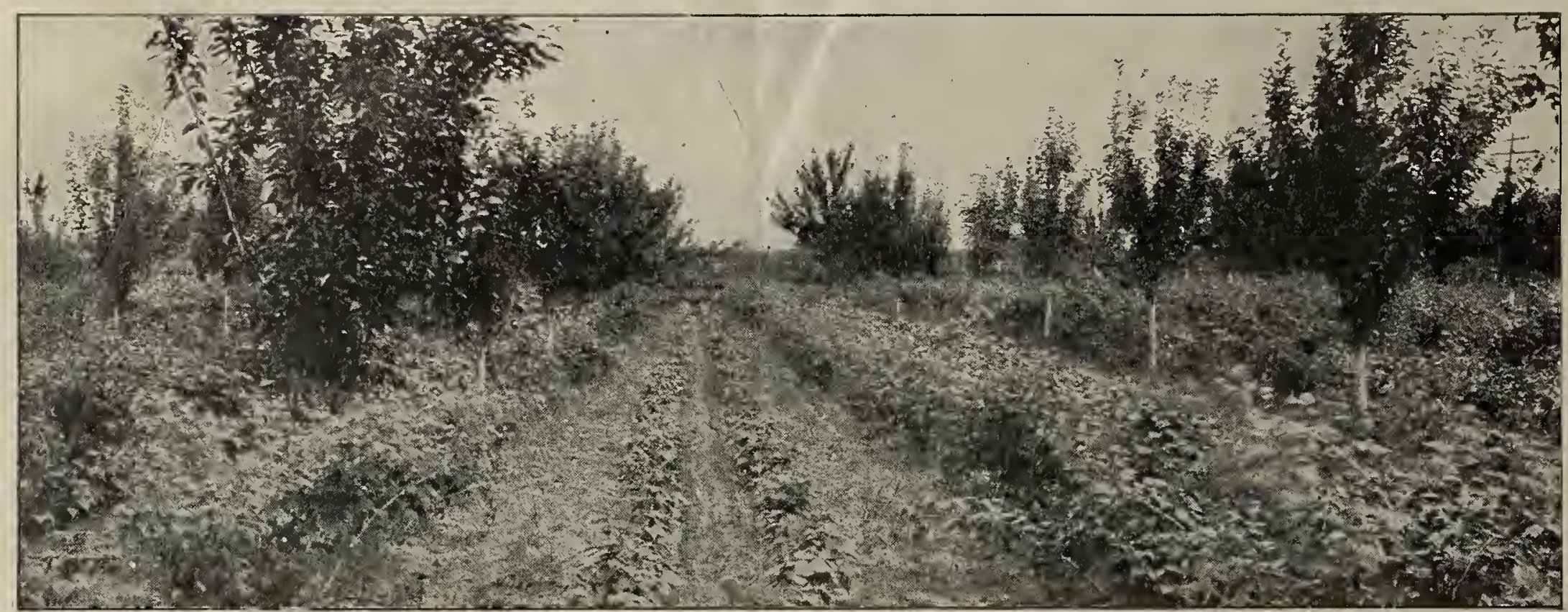

Berries between trees on a ten-acre farm near Benton Harbor, Mich., which has kept its owner since he started

\section{It is Easy to Make Money Growing Berries}

You can use berries to get a double profit from one piece of land, just as the owner of the property shown above has done. He plants Strawberries and Raspberries between the rows of fruit trees, and makes as much from the space between the trees as he will make from the trees themselves when they come into bearing. This is the easiest and cheapest way to make an orchard.

\section{Make Extra Money by Growing Berry Plants for Sale}

Buy the improved varieties of Raspberries, Blackberries, Strawberries and true Himalaya Berry, make money from the fruit-crop and, at the same time, make as much or more money supplying plants to farmers, gardeners and others.

Let us look at what we can do with such a proposition: Rent five acres of ground, with the privilege of buying, for five years. Then plant it to Plum Farmer Blackcap Raspberries, 5 feet apart each way. This will require $\mathrm{I}, 750$ plants to the acre, or 8,750 in all, at $\$$ IO per thousand, making the whole cost of the five-acre berry-plantation only $\$ 87.50$.

When the plants are 18 inches high, pinch off the tips. Do this in May each season, and then they will branch. When the branches reach the ground, about September I, get a sharp stick, make a hole in the ground and put the tips of the canes down about 3 inches deep, press the soil around the tips, so they will not spring up again. They will take root quickly, and the next spling you will have young piants that sell readily to the nursery trade at from $\$ 4.00$ to $\$ 5.00$ per thousand, or to local trade for several times that price. One man can put under from 4,000 to 5,000 tips in one day.

By growing both plants and fruit you have a money-making "crop" twice a year. The fruit from the five acres, sixteen months from planting, will at least yield Ioo-quart crates to the acre, or 500 crates from the five acres. The second season the crop will be 300 crates to the acre. We get for our Plum Farmer Blackcap Raspberries from $\$ 1.40$ to $\$ 1.60$ a crate.

Now ask yourself, where can you invest money that will bring in such returns as this?

\section{Condensed Price-List of Berrydale Plants}

Six plants at dozen rates, 50 at I00 rates, 500 at $I, 000$ rates. I,000,000 berry plants for sale

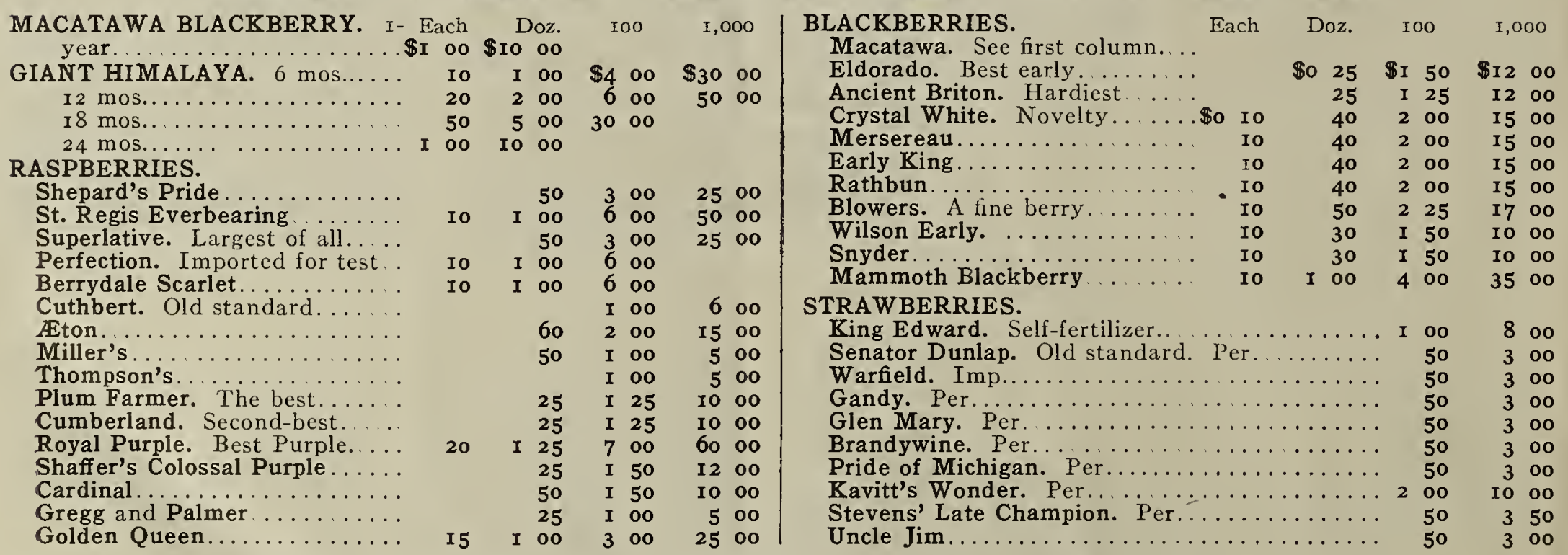

\section{Special Premium on Early Orders}

It helps me a whole lot when people order early, because then I can get the plants dug, packed and shipped before we are swamped with business. Just to make it worth your while to order a week or two earlier than you would anyway, I will allow a discount of ro per cent on each order of \$I or more sent before March I5. Just clip out the coupon at the left and pin it to your order, and I will accept it for Io cents on each dollar.

\section{$10 \%$ Discount}

THIS COUPON is good for Io per 1 cent cash discount from prices here and in my catalogue. Cut it out and send it with your order, enclosing only 90 cents for each dollar of the total amount of money called for by printed prices.

\section{A. MITTING, Proprietor}

BERRYDALE EX PERIMENT GARDENS, Holland, Mich. 